\title{
HIKMAH DALAM AL-QUR'ĀN DAN IMPLEMENTASINYA DALAM MEMBANGUN PEMIKIRAN ISLAM YANG INKLUSIF
}

\author{
Mukhammad Zamzami \\ Universitas Islam Negeri Sunan Ampel Surabaya, Indonesia \\ E-mail: mukhammadzamzami@gmail.com
}

\begin{abstract}
This article attempts to trace and describe the correlation of hikmah (wisdom) and inclusivity in the Qur'ān along with their connection to the dynamics of development of contemporary Islamic thought. Hikmah in its implied meaning as wisdom of thinking-which puts emphasis on reason, acquirement, and ability-has been compatible with the inclusivity of Islamic thought in several aspects. Such inclusivity can be observed, among others, within the following aspects, are: firstly, inclusive refers to tolerance and it implies acceptance toward plurality, heterogeneity, and self-willingness to actively participate in it. Inclusive thought brings about tolerance. Tolerance explicitly comprises conformity with wisdom in which each entity highly emphasizes public benefit. Secondly, inclusive means freedom. Freedom requires one's discretion to use reason as a means of truth search. This meaning is closely related to wisdom, which perceives thinking and reasoning as a way to reach the truth. Thirdly, inclusive also means freedom. Freedom necessitates a universal and non-coercive Islamic thought. Terminologically, it has similar meaning to wisdom where each side lays emphasis on the implementation of a universal Islamic thought. Islam provides its adherents wide space to freely choose their way of life, including right to embrace certain religious ideology.
\end{abstract}

Keywords: Wisdom; inclusivity; Islamic thought.

\section{Pendahuluan}

Agama dalam pengertian etimologinya berasal dari dua kata, yaitu a dan gam. A bermakna tidak dan gam adalah kacau. Agama berarti ketidakkacauan atau dalam bahasa sederhananya adalah keteraturan.

\footnotetext{
${ }^{1}$ Thaib Thahir Abdul Muin, Ilmu Kalam II (Jakarta: Widjaja, 1973), 5.
} 
Kedudukan agama sebagai keteraturan mengisyaratkan bahwa ia merupakan sumber nilai moral mencakup keseluruhan aktivitas hidup manusia, baik bersifat pribadi, sosial, dan khususnya menyangkut ritualitas ketuhanan. Persisnya, agama adalah sumber nilai keseluruhan hidup, ${ }^{2}$ landasan dalam berpikir maupun bertindak yang menuntun setiap penganutnya agar senantiasa menjunjug tinggi prinsip moralitas, humanisme, dan religiositas. Agama selalu menyebarkan pesan-pesan kedamaian, keluhuran, kebajikan, dan kebaikan universal bagi seluruh umat manusia. Secara teologis, kedudukan agama sebagai sumber moral adalah pengertian yang berlaku umum bagi semua agama-agama dunia, ${ }^{3}$ baik agama samawi maupun non-samawi.

Begitupun dengan Islam, semenjak awal kehadirannya Islam memiliki visi universalitas yang bertumpu pada penegakan nilai-nilai kemanusiaan dan moralitas umat (rahmah li al-álamin). Visi tersebut tercemin jelas dalam kerasulan Muhammad yang memiliki tujuan utama melakukan penguatan dan perbaikan moral manusia. ${ }^{4}$ Melalui kemunculan Nabi Muhammad dan ajaran Islam secara khusus, kehidupan manusia yang dulunya dipenuhi oleh ragam keburukan, pertentangan, dan segala bentuk praktik amoral yang berakar pada kebodohan (Jāhilīyah), kemudian diubahnya pada jalan moralitas, keadilan, dan pembelaan terhadap semua prinsip kemanusiaan. Semuanya bermuara pada ketercerahan hidup, baik dalam berpikir, bertindak, bersikap, dan berperilaku. Aspek pencerahan inilah yang kemudian juga ditanamkan dalam prinsip ajaran Islam hingga sekarang, sebagaimana termuat dalam sumber utamanya, yakni alQur'ān dan Hadis. Dalam kaitan ini, al-Qur'ān sebagai bagian kredo keagamaan Islam selain berstatus sebagai kitab suci juga berfungsi sebagai perangkat moral yang berusaha menegakkan nilai universal, ${ }^{5}$ khususnya yang bersentuhan dengan prinsip kemanusiaan.

2 Petrus Lakonawa, "Agama dan Pembentukan Cara Pandang Serta Perilaku Hidup Masyarakat”, Jurnal Humaniora, Vol. 4, No. 2 (2013), 792.

3 Ika Fatmawati Faridah, "Toleransi Antarumat Beragama Masyarakat Perumahan", Jurnal Komunitas, Vol. 5, No. 1 (2013), 20.

4 Arif Nuh Safri, "Otentisitas Risalah Kenabian; Pluralisme dan Kemanusiaan", Jurnal Esensia, Vol. 13, No. 1 (2012), 169.

5 Ghozali Munir, "Al-Qur'an dan Sejarah Realitas Umat Manusia”, Jurnal AtTaqaddum, Vol. 4, No. 1 (2012), 2. 
Kedudukan fungsi al-Qur'ān sebagai pegangan hidup umat Islam, ${ }^{6}$ mensyaratkan kehadiran dirinya dalam kehidupan nyata. Pada titik ini, al-Qur'ān yang di dalamnya memuat nilai dan ajaran Islam mengambil bagian dalam ruang kehidupan supaya dapat diterjemahkan sebaik dan sesempurna mungkin oleh segenap pemeluk dan penganutnya. Untuk dapat menerjemahkan pesan Allah, al-Qur'ān tidak dapat dipandang sebagai susunan teks mati. Sebaliknya, ia harus dilihat sebagai teks hidup. ${ }^{7}$ Tesis bahwa al-Qur'ān adalah entitas hidup didasarkan pada kenyataan kemunculan al-Qur'ān sendiri yang tidak hadir di ruang hampa, melainkan ia muncul di tengah realitas masyarakat yang memiliki varian konteks sosial. Karenanya, tidak dapat dibenarkan jika kemudian proses interpretasi al-Qur'ān dilakukan sekadar berpijak pada teks zahir, tanpa melibatkan horizon sosial yang melatarinya. Dalam kerangka berpikir inilah akal—melalui aktivitas berpikir dan menalar secara langsung-menemukan peran dan fungsinya, yakni sebagai instrumen dialektis untuk mencari, menelusuri, dan menemukan sisi orisinalitas makna (original meaning) di balik konteks sosial itu sendiri. ${ }^{8}$

Pada dasarnya, Islam menempatkan dirinya sebagai jalan kebijaksanaan (bikmah) yang membuka diri terhadap keberadaan akal, ilmu, dan menempatkan sesuatu berdasarkan tempatnya masingmasing. Pengakuan al-Qur'ān terhadap keberadaan akal mengindikasikan atas ketiadaan pertentangan antara akal dan al-Qur'ān. Pesanpesan yang terkandung dalam al-Qur'ān akan dapat termanifestasikan dalam kehidupan manakala diolah melalui akal. Tanpa aktualitas akal, maka teks al-Qur'ān beserta makna yang terkandung di dalamnya akan menjadi realitas absurd. Baik akal maupun al-Qur'ān keduanya memiliki relasi dialektis yang bersifat produktif yang dapat menghasilkan sintesis dan berfungsi strategis bagi keberlangsungan hidup dan peradaban manusia. Karenanya, menganulir kehadiran dalam kedudukan akal sebagai instrumen perwujudan hiłkmah Islam,

\footnotetext{
6 "Kitab (al-Qur'ān) ini tidak ada keraguan padanya; petunjuk bagi mereka yang bertakwa" (Q.S. al-Baqarah [2]: 2).

7 Moh. Muhtador, "Pemaknaan Ayat al-Qur'an dalam Mujahadah: Studi Living Qur'an di PP Al-Munawwir Krapyak Komplek al-Kandiyas", Jurnal Penelitian, Vol. 8, No. 1 (2014), 96.

8 Ade Jamarudin, “Eksistensi Fungsi Akal Manusia Perspektif al-Qur’ān”, Jurnal AnNur, Vol. 4, No. 1 (2015), 78.

9 Jamāl al-Bannā, al-Islām Kamā Tuqaddimuh Da'wat al-Iḅaà' al-Islāmì (Kairo: Dār alFikr al-Islāmī, 2004), 107.
} 
itu sama halnya dengan penegasian terhadap rekam jejak peradaban umum manusia yang telah berlangsung dari masa klasik hingga postmodern. ${ }^{10}$

Fakta bahwa Islam menempatkan dirinya dalam lingkar kebijaksanaan (hikmah), maka sudah sepatutnya setiap pemikiran yang berkembang juga berorientasi pada nilai kebijaksanaan. Kebijaksaan yang dimaksud di sini adalah terciptanya otonomi dalam mengkreasi metode-metode atau menifestasi baru dalam memahami bahasa agama. Ia berisi prinsip-prinsip keterbukaan seperti kebebasan, berpikir rasional, berorientasi keadilan dan kemaslahatan, yang kesemuanya berpangkal pada penghargaan dan penghormatan nilainilai kemanusiaan. ${ }^{11}$ Sampai pada batasan ini, boleh dibilang unsur kemanusiaan adalah sentral keberlangsungan nalar al-Qur'ān, dan jika al-Qur'ān berkedudukan sebagai sumber segala nilai dan norma kehidupan, maka manusia dengan segala kemampuan dan daya berpikirnya adalah saluran atau instrumen utama.

Berkenaan dengan term kebijaksanaan (hikmab), tema tentang kebijakasanaan sesungguhnya sudah banyak didiskusikan dalam khazanah pemikiran Islam. Dalam banyak hal, tema ini menjadi pembahasan fundamental karena posisi pentingnya dalam ajaran Islam. Salah satu pemikir kontemporer yang mebicarakan konsep bikemah adalah Jamāl al-Bannā (1920-2013). Menurutnya, nilai kebijaksanaan dalam pemikiran Islam mengandung memuat empat hal penting, yakni humanisme, kemaslahatan, keadilan, dan rasionalisme. ${ }^{12}$ Humanisme artinya manusia sebagai jantung nalar al-Qur'ān. Dengan demikian al-Qur'ān beserta segenap pesan yang termuat di dalamnya harus dapat menjalin sinergitas dengan akal. ${ }^{13}$ Rasionalisme memuat pengertian bahwa akal dengan segala kelebihannya berfungsi sebagai jalan memperkokoh keimanan. Kemaslahatan mensyaratkan bahwa setiap pemikiran Islam harus memiliki orientasi pada kebaikan hidup manusia, khususnya bagi masyarakat Muslim sendiri. ${ }^{14}$ Pentingnya visi

10 Jamāl al-Bannā, Tajdìd al-Islām wa I'ädat Ta'sìs Manzümat al-Ma'rifah al-Islämīyah (Kairo: Dār al-Fikr al-Islāmī, 2005), 257.

11 al-Bannā, al-Islàm Kamā Tuqaddimuh, 70.

${ }^{12}$ Mukhammad Zamzami, "Teologi Humanis Jamâl al-Bannâ: Sebuah Rekonstruksi Epistemologis Studi Keislaman”, Teosofi: Jurnal Tasawuf dan Pemikiran Islam, Vol. 2, No. 1 (2012), 193.

13 Jamāl al-Bannā, Istrātìizyat al-Da'wah al-Islāmìyah fì Qarn 21 (Kairo: Dār al-Fikr alIslāmī, 2000), 60-63.

14 al-Bannā, al-Islām Kamā Tuqaddimuh, 58. 
kemaslahatan dan humanisme dalam pemikiran Islam didasarkan pada kenyataan tipologi masyarakat Muslim sebagai satu realitas masyarakat inklusif, yaitu masyarakat yang di satu sisi terdiri dari beragam identitas kesukuan, namun pada saat bersamaan mereka memiliki kesediaan diri untuk bersikap terbuka dengan kelompok dan golongan di luarnya. Untuk itu, setiap bentuk pemikiran dan gagasan tentang Islam harus dapat menjalin keselarasan, atau bahkan menjadi penguat inklusivitas tersebut.

Berdasarkan kerangka berpikir inilah dapat disimpulkan, bahwa diskursus mengenai term kebijaksanaan (bikmah) dan inklusivitas merupakan term keislaman yang memiliki landasan kuat, baik secara sosiologis maupun teologis. Secara sosiologis term hikmah dan inklusivitas berakar dari kenyataan masyarakat Islam yang plural dan majemuk, sehingga keberadaannya harus dirawat bersama. Sedangkan secara teologis, kedua term tersebut memiliki landasan cukup jelas yang diadopsi langsung dari sumber otoritas al-Qur'ān surah alHujarāt ayat 13. Berkenaan dengan studi ini, artikel ini menelusuri dan mendeskripsikan perihal hubungan term hikmah dan inklusivitas dalam al-Qur'ān dan kaitannya dengan dinamika perkembangan pemikiran Islam kontemporer.

\section{Hikmah dalam al-Qur'ān}

Term hikmah (Arab: bikmah) adalah bagian tak terpisahkan dari Islam. Ajaran dan konsep ini menduduki aspek cukup penting sebagaimana konsep-konsep Islam lainnya. Dalam al-Qur'ān, kata hikmah dapat dijumpai di banyak ayat, bahkan di beberapa ayat tertentu, lafal hikmah senatiasa ditempatkan pada tema-tema strategis. Besarnya perhatian Islam terhadap pembelajaran hikmahsebagaimana tertuang jelas dalam al-Qur'ān—secara langsung mmenempatkan dirinya sebagai salah satu bagian penting pembahasan dan ajaran Islam. Baik yang bersifat ritual ('ubüdiyab), sosial (mu'ámalah), bahkan hingga menyangkut aktivitas keagamaan yang bersifat praktis sekalipun, seperti halnya dakwah (Q.S. al-Nahl [16]: 125). ${ }^{15}$ Dakwah bukan sekadar tentang menyampaikan atau menyeru umat pada jalan kebaikan dan kebenaran Islam, tapi juga berkenaan

\footnotetext{
15 "Serulah (manusia) kepada jalan Tuhan-mu dengan hikmah dan pelajaran yang baik dan bantahlah mereka dengan cara yang baik. Sesungguhnya Tuhanmu yang lebih mengetahui tentang siapa yang tersesat dari jalan-Nya dan dialah yang lebih mengetahui orang-orang yang mendapat petunjuk" (Q.S. al-Nahl [16]: 125).
} 
dengan kesediaan dan kesadaran diri untuk senantiasa menjunjung tinggi sikap dan perilaku hikmah. Pertanyaan besarnya kemudian, apa yang dimaksud dengan konsep hikmah dalam Islam? Jika benar term hikmah memiliki landasan jelas dalam al-Qur'ān, bagaimana kemudian al-Qur'ān memaknai term hikmah itu sendiri? Sebelum lebih jauh masuk pada dua pertanyaan ini, terlebih dahulu akan dijelaskan sekilas tentang sejarah genealogis hikmah dalam diskursus pemikiran Islam, kemudian setelah itu diikuti oleh penjelasan konseptual hikmah dari berbagai perspektif.

Secara genealogis, diskursus hikmah dalam sejarah pemikiran Islam, jika ditinjau berdasarkan sumber tekstualnya, sesungguhnya telah ada bersamaan dengan kehadiran Islam itu sendiri. Demikian dapat dilacak langsung di dalam al-Qur'ān, yang secara eksplisit telah banyak menyinggung kata hikmah. Jika ditelusuri berdasarkan jumlahnya, sekurang-kurangnya terdapat 2010 kata bikmah dalam berbagai bentuk gramatikalnya terdapat dalam keseluruhan ayat alQur'ān. Hikmah dengan lafal ḥakama terulang sekali, ḅukman 11 kali, dan hukm sebanyak 53 kali, yaḥumu sebanyak 23 kali, ạ̣käm sekira tiga kali, dan kata ḥäkim sebanyak 81 kali. Sedangkan kata ḩikmah dalam bentuk gramatikal aslinya berjumlah 20 kali. Jika dikategorisir berdasarkan ayat dan surahnya, keseluruhan kata hikmah dalam semua bentuk gramatikal di atas tersebar di 12 surah dan 19 ayat al-Qur'ān. ${ }^{16}$

Adapun dalam hal pemikiran, diskursus hikmah dalam Islam telah menemukan ruangnya pada era klasik, tepatnya ketika pada masa Ibn Rushd (1126-1198). Hanya, pada awal mula kemunculannya ini, diskursus hikmah lebih dikenal sebagai tradisi filsafat, yang pada masanya dikenal sebagai aliran filsafat iluminasi (ishräqi). ${ }^{17}$ Menariknya, meski diskursus ini muncul pada masa kegemilangan kefilsafatan Ibn Rushd, pemikiran tentang hikmah tidak muncul dari dirinya, melainkan dari seorang pemikir Islam Persia, Shihāb al-Dīn alSuhrawardī (1153-1191 M). ${ }^{18}$ Pada periode awal kemunculannya,

\footnotetext{
${ }^{16}$ Muhammad Fuād 'Abd al-Bāqī, Mu'jam Mufahras li Alfäă al-Qur'ān al-Karìm (Beirut: Dār al-Fikr, 1992), 269-273.

17 Seyyed Hossein Nasr, Ensiklopedi Tematis Filsafat Islam, terj. Tim Penerjemah Mizan (Bandung: Mizan, 2003), 546.

${ }^{18}$ Eko Sumadi, "Teori Pengetahuan Ishraqiyyah (Iluminasi) Syihabudin Suhrawardi", Fikrah: Jurnal Ilmu Aqidah dan Studi Keagamaan, Vol. 3, No. 2 (2015), 281.
} 
filsafat ini merupakan pengintegrasian antara dua jenis tradisi pemikiran berbeda, yakni epistemologi paripatetik dan tradisi mistis. ${ }^{19}$

Semenjak kemunculan pemikiran Suhrawardī, dinamika pemikiran Islam masuk pada perkembangan pemikiran yang semakin maju. Konstruksi filsafat Suhrawardī tentang hikmah menjadi penguat keberadaan aliran filsafat-filsafat sebelumnya, seperti halnya aliran filsafat Ibn Rushd. Suhrawardī melalui pemikiran besarnya seolah menjadi oase bagi perjuangan Ibn Rushd, yang saat itu tengah berusaha keras mengembalikan dan menghidupkan kembali kedigdayaan filsafat Islam. Penegasan Suhrawardī sebagai peletak pemikiran hikmah dalam diskursus Islam tergambar jelas ketika dirinya lebih suka menyebut produk pemikirannya dengan sebutan bikmat al-ishrāq daripada falsafat al-ishrāq, ${ }^{20}$ sebagaimana banyak disematkan oleh pemikir di luarnya. Dalam perkembangan berikutnya, di tengah dominasi pemikiran filsafat Ibn Rushd, pemikiran Suhrawardī tentang hikmah kemudian menjelma sebagai aliran pemikiran baru pada masanya yang menarik perhatian banyak kalangan, terutama pada periode pascakeberadaan Ibn Rushd. ${ }^{21}$

Menurut beberapa kalangan, gagasan besar Suhrawardī sejatinya merupakan wujud dari kefilsafatan. Meski Suhrawardi sendiri tidak menyebutnya sebagai tradisi filsafat, namun kenyataan bahwa konsep hikmah sebagai satu perangkat sistem kebijaksanaan dalam berpikir dan bernalar, sudah cukup untuk mengelompokkan hikmah sebagai aliran filsafat pada masanya. Barangkali kenyataan inilah yang kemudian mendorong Ibn Rushd menggolongkan hikmah sebagai bagian dari filsafat yang dibungkus dalam redaksi dan terminologi berbeda. Sejalan dengan Ibn Rushd, kalangan peneliti kontemporer, seperti halnya Henry Corbin, Oliver Leaman dan Toshihiko Izutsu berpandangan, hikmah merupakan suatu wujud pemikiran yang menjadi keselarasan dengan makna filsafat Islam sesungguhnya. ${ }^{22}$ Bahkan Corbin menegaskan, hikmah mengandung makna lebih sesuai

19 Abdullah, "Hikmah al-Israqiyah: Menelaah Sisi Eksistensialisme Teosofi Transenden Mulla Sadra, Jurnal Sulesana, Vol. 7, No. 2 (2012), 3.

${ }^{20}$ Seyyed Hossein Nasr dan Oliver Leaman, Ensiklopedi Tematis Filsafat Islam: Buku Pertama, terj. Tim Penerjemah (Bandung: Mizan, 1996), 32.

21 Asep N. Musadad, "Tafsir Al-Qur'an dalam Tradisi Filsafat Hikmah: Analisis Materi Filosofis Tafsir Ayat al-Kursy, Karya Mulla Sadra" (Tesis--Universitas Islam Negeri Sunan Kalijaga Yogyakarta, 2016), 16.

22 Madjid Fakhry, A History of Islamic Philosophy (New York: Colombia University Press, 1983), 73. 
dengan term sophia sebagai akar kata filsafat modern. ${ }^{23}$ Klaim Corbin tersebut kemudian diperkuat oleh pemikir Islam kontemporer, Seyyed Hossein Nasr, dirinya menyebut bahwa di belahan timur dunia Islam, konsep al-hikmah al-ilähijah Suhrawardī secara praktis menjadi bersinonim dengan kata falsafah. ${ }^{24}$

Dalam pengertian umum, hikmah memiliki arti kebijaksanaan (dari Allah); sakti atau kesaktian; arti atau makna yang dalam (manfaat). ${ }^{25}$ Dari sekain pengertian ini-dalam interpretasi umumhikmah lebih banyak disandingkan dengan lafal kebijaksanaan. Konsep kebijaksanaan di sini mengandung dua arti, yakni kepandaian menggunakan akal budinya (pengalaman dan pengetahuan); kecakapan bertindak apabila menghadapi kesulitan dan sebagainya. ${ }^{26}$ Berdasar pada pengertian umum di atas, konsep hikmah dapat dikelompokkan pada dua poin penting, yaitu; Pertama, kepandaian dalam berpikir yang bertumpu pada pengetahuan dan pengalaman. Dengan demikian, berhikmah sama artinya dengan perwujudan diri yang berilmu, terdidik, terpelajar dan berpengalaman tentang suatu yang telah dijalani, dirasai, ditanggung, dan sebagainya. Dengan berilmu, praktis akan membuat dirinya tercerahkan, sehingga dapat membedakan antara yang baik-buruk dan benar-salah. Kedua, kecakapan dalam bertindak untuk menjauhkan diri dari kesulitan. Bahwa hikmah tidak sebatas pada pemenuhan kemampuan akal budi, namun juga menghindarkan diri dari segala bentuk kesukaran, membebaskan manusia dari segala bentuk permasalahan hidup. Mempunyai semangat pembelaan yang besar terhadap nilai-nilai kebajikan dan keluhuran hidup.

Adapun hikmah dalam pengertian khusus yang didasarkan pada kajian atau pendapat ilmuan tertentu memuat definisi cukup bervariasi. Secara umum, ada banyak tokoh yang terlibat di dalamnya, baik mereka yang tercatat sebagai ilmuan klasik hingga modern. Menariknya, masing-masing dari mereka menghadirkan ragam interpretasi. Pada momen tertentu mereka menolak pendapat lainnya, namun tidak ditampik juga pada momen yang lain mereka saling mendukung dan mengamini. Beberapa di antaranya adalah Jamāl al-

\footnotetext{
${ }^{23}$ Ibid., 15-18.

${ }^{24}$ Seyyed Hossein Nasr, History of Islamic Philosophy from Its Origin to The Present: Philosophy in Land of Prophecy (New York: State University of New York, 2006), 1314.

${ }^{25}$ KBBI Online( https://kbbi.web.id/), diakses pada 17 Februari 2015.

${ }^{26} \mathrm{Ibid}$.
} 
Bannā, Ibn Rajab (1335-1393), Maḥmūd al-Alūsī (1802-1854), dan Ibn Rushd. Berikut akan diuraikan definisi konsep hikmah berdasarkan pembacaan masing-masing tokoh di atas.

Menurut Jamāl, term hikmah merupakan tema tidak asing dalam Islam, term ini sendiri sudah banyak tersebar luas di dalam sumbersumber utama Islam, khususnya al-Qur'ān. Begitu kentalnya konsep hikmah dalam ajaran Islam, hingga al-Bannā menyebut hikmah sebagai bagian integral Islam. ${ }^{27}$ Berbicara Islam sama artinya dengan membincangkan hikmah. Demikian karena Islam adalah hikmah, dan hikmah sendiri merupakan visi keberislaman sesungguhnya. Berkenaan dengan definisi hikmah ini, Jamāl menegaskan bahwa hakikat hikmah adalah terciptanya kebebasan atau otonomi dalam menciptakan ragam metode atau manifestasi untuk memahami "bahasa agama". Ia berisi prinsip-prinsip keterbukaan seperti kebebasan, berpikir rasional, berorientasi keadilan dan kemaslahatan dalam memahami teks-teks al-Qur'ān dan Sunnah. Dengan memasuki dimensi kehidupan secara umum, hikmah hadir untuk melengkapi kekurangan—dengan ijtihad—dalam agama itu sendiri. ${ }^{28}$

Jauh sebelum Jamāl berbicara tentang hikmah, al-Shāfíī dan Ibn Rushd tercatat sebagai ulama klasik yang terlebih dahulu memberi perhatian cukup besar terhadap pembahasan hikmah. Menurut alShāfí', lafal hikmah yang dimaksud dalam banyak ayat-ayat al-Qur'ān mempunyai kepadanan arti dengan Sunnah. ${ }^{29}$ Hal tersebut didasarkan pada penjelasan Islam yang menyebutkan bahwa Allah membekali kerasulan Nabi Muhammad dengan Sunnah, di mana semua ajaran yang terkandung di dalamnya memiliki universalitas sebagaimana alQur'ān. ${ }^{30}$ Berbeda dengan penjelasan Jamāl dan al-Shāfíî́, Ibn Rushd menyebut hikmah sebagai kata lain dari filsafat. ${ }^{31}$ Bila filsafat dipahami sebagai jalan berpikir untuk mendapati kebenaran sejati melalui penggunaan akal yang sistematis dan terstruktur, maka hikmah pun juga demikian. Jika dimati lebih mendalam, pendapat Ibn Rushd tentang kesamaan konseptual antara hikmah dan filsafat, dalam batasan-batasan tertentu menemukan titik kebenarannya. Persisnya ketika memaknai konsep hikmah dan filsafat sebagai kebijaksanaan

27 al-Bannā, Tajdìd al-Islām, 256-257.

28 al-Bannā, al-Islām Kamā Tuqaddimuh, 108.

${ }^{29}$ al-Bannā, Tajdìd al-Islām, 442.

30 Abū 'Abd Allah Muḥammad b. Idrīs al-Shāfícín, al-Risālah (Beirut: Dār al-Kutub al'Ilmīyah, 1939), 78.

31 al-Bannā, al-Islàm Kamā Tuqaddimuh, 107. 
berpikir yang bertumpu pada kemampuan akal budi, baik itu berupa pengetahuan atau pengalaman. Pembacaan ini menjalin kesejalanan dengan pendapat cendekiawan Muslim Indonesia, M. Quraisy Shihab, bahwa hikmah merujuk pada diperolehnya pengetahuan yang didukung oleh pengalaman yang benar, dan pengalaman itu dilandasi oleh ilmu. ${ }^{32}$

Selain nama-nama di atas, penjelasan tentang hikmah juga datang dari tokoh pemikir Islam lainnya bernama al-Alūsī. Menurutnya, hikmah yang dimaksudkan dalam ayat-ayat al-Qur'ān identik dengan keadilan, yakni meletakkan segala parkara berdasarkan tempatnya, atau mengembalikan sesuatu permasalahan berdasarkan ajaran agama, baik ajaran yang dimaksud bersumber dari kitab al-Qur'ān maupun dari hadis. ${ }^{33}$ Dalam penjelasan lebih luas, al-Alūsī mengelompokkan hikmah ke dalam dua bagian, yakni hikmah dalam konteks teoretis dan hikmah dalam konteks praktis. Konteks teoretis dalam pengertian ini bukan dalam arti populernya, yakni suatu asumsi atau pendapat yang didasarkan pada penelitian dan penemuan, didukung oleh data dan argumentasi dengan tingkat kebenaran telah terbukti. Yang dimaksud teoretis dalam kajian ini lebih pada mengetahui rahasiarahasia dari segala sesuatu dan mengetahui korelasi antara segala sebab dengan akibatnya. Hikmah model ini dapat diketahui melalui dua hal sekaligus, yakni pengetahuan atau ilmu dan penalaran. Adapun yang dimaksud hikmah praktis adalah hikmah yang berorientasi keadilan, yakni menempatkan sesuatu berdasarkan tempatnya. ${ }^{34}$ Jika mengacu pada penjelasan ini, hikmah akan benar-benar terwujud manakala melibatkan dua model hikmah sekaligus, baik praktis maupun teoretis. Yakni upaya pencarian kebenaran yang tidak saja didasarkan pada penggunaan akal, pengetahuan, dan penalaran. Lebih dari itu harus dapat mengamalkan dan mendudukkannya secara proporsional berdasarkan tempat masing-masing.

Pada kesempatan yang lain, Ibn Rajab mengartikan hikmah sebagai istilah umum yang mencakup semua makna dan berkenaan dengan segala hal yang dapat menghindarkan dari dua keburukan sekaligus, yakni: pertama, mencegah dari segala bentuk kebodohan,

32 M. Quraish Shihab, Secercab Cahaya Ilabi Hidup Bersama Al-Qur'ān (Bandung: Mizan, 2007), 93.

33 Shihāb al-Dīn al-Alūsī, Rūḥ al-Ma'ānī fì Tafsìr al-Qư'àn al-Aẓ̛im wa al-Sab'alMathanì (Beirut: Dār al-Kutub al-'Ilmīyah, 2001), 285.

34 Khoirul Amnu Harahap, 355 Kunci Menjadi Kekasib Allab Sepanjang Masa (Tanggerang: PT. Tangga Pustaka, 2009), 9. 
yang karenanya kehidupan manusia menjadi jumud dan peradaban manusia berjalan mundur dan terbelakang, ${ }^{35}$ dan kedua, mencegah dari berbagai sikap dan perilaku negatif yang dapat menyebabkan terjadinya pertentangan, kekacauan, dan distabilitas di kalangan masyarakat secara menyeluruh. Istilah pencegahan dalam pembacaan Ibn Rajab tersebut didasarkan pada akar kata hikmah, yang secara gramatikal arab berasal dari lafal hakama. Kata ini mengunakan huruf $h \bar{a}$, käf dan mim yang ditafsirkan oleh banyak kalangan sebagai kata alman', yang berarti menghalangi atau mencegah. ${ }^{36}$

Jika hikmah menemukan ruang eksistensinya dalam sudut pandang historis dan pendefinisan yang jelas, maka bagaimana kemudian dapat dipastikan bahwa hikmah memiliki akar legitimasi kuat berdasarkan ajaran Islam sesungguhnya? Bahwa hikmah memuat dasar teologis jelas yang secara langsung bersandar pada teks-teks keislaman yang benar adanya, sehingga keberadaannya dapat dipertanggungjawakan secara hukum otoritas keislaman, al-Qur'ān. Untuk menjawab pertanyaan ini, maka berikut akan diuraikan beragam pemikiran intelektual Muslim, kaitannya dengan landasan tekstual hikmah, terutama yang tertuang langsung dalam al-Qur'ān sebegai satu-satunya sumber tertinggi. Beberapa tokoh pemikir Islam yang berupaya keras menelusuri landasan hikmah dalam al-Qur'ān, di antaranya al-Shāfíīi, Ibn Rushd, kedua tokoh ini dapat dikelompokkan sebagai pemikir abad klasik. Selain itu, terdapat juga beberapa tokoh pemikir modern-kontemporer, mereka yang tergabung dalam kelompok ini adalah Jamāl al-Bannā, Armehedi Mahzar (1947), Salman Ghonim, dan Daniel Madigan. Untuk dapat memberi pemahaman yang jelas, berikut akan disampaikan hikmah dalam alQur'ān berdasarkan pengelompokan berikut:

a) Hikmah sebagai Sunnah

Berdasarkan arti terminologis, sunnah memiliki arti jalan yang biasa ditempuh; kebiasaan; aturan agama yang didasarkan atas segala apa yang dinukilkan dari Nabi Muhammad, baik perbuatan, perkataan, sikap, maupun kebiasaan yang tidak pernah ditinggalkannya. ${ }^{37}$ Jika mengacu pada pengertian ini, maka sunnah yang dimaksud di sini

\footnotetext{
35 Zayn al-Dīn Abī al-Faraj b. Rajāb al-Hanbalī, Fatḥ al-Bārì bi Sharḥ al-Bukhārū, Vol. 1 (Madinah: Maktabat al-Ghurabā', 1999), 166.

36 Abū al-Ḥusayn Aḥmad b. Fāris b. Zakariyā, Mưjam Maqāyìs al-Lughah (Beirut: Dār al-Fikr li al-Tarbīyah wa al-Nashr wa al-Tawzī‘, 1998), 277.

${ }^{37}$ Muḥammad Abū Zahw, al-Hadìth wa al-Muḥaddithūn (Beirut: Dār al-Fikr, t.th.), 9.
} 
indetik degan segala sikap, perilaku, dan perkataan Nabi Muhammad. Dengan demikian, hikmah menurut al-Qur'ān dalam artinya sebagai sunnah meniscayakan pada keteladanan Nabi Muhammad. Baik itu berbentuk ajaran, sikap, perilaku, maupun perkataannya.

Sedangkan bagi al-Shāfíî, terminologi hikmah dalam al-Qur'ān dapat ditelusuri dalam kedudukannya sebagai hadis Nabi. ${ }^{38}$ Berkenaan dengan ini, al-Shāfíi menjelaskan bahwa hikmah dalam peran dan fungsinya sebagai hadis, praktis menyimpan makna universal yang mencakup segala dimensi hidup manusia. ${ }^{39}$ Baik itu yang mengatur hubungan manusia dengan sesamanya (mu'ämalab), maupun menyangkut hubungan manusia dengan tuhan ('ubüdìyah). Untuk menguatkan pendapatnya ini, al-Shāfíi kemudian menyebutkan tujuh ayat al-Qur'ān yang bekenaan langsung dengan konsep hikmah, yaitu al-Baqarah [2]: 129, 151, 231; Āl 'Imrān [3]: 164; al-Jumu'ah [62]: 2; alNisā' [4]: 113; dan al-Aḥzāb [33]: 34. Untuk menguatkan uraiannya, alShāfíī kemudian menjelaskan, bahwa di balik penempatan kata ḩikmah yang diletakkan setelah kata al-Kitāb dan ayät Allah yang bermakna alQur'ān, tersimpan makna dan kebenaran khusus, bahwa hakikat dari hikmah ialah Sunnah itu sendiri.

b) Hikmah sebagai Aktivitas Kefilsafatan

Jika al-Shāfíī mereduksi hikmah dalam al-Qur'ān dalam bentuk sunnah, maka yang demikian berbeda jauh dengan Ibn Rushd. Menurutnya, yang dimaksud hikmah dalam al-Qur'ān adalah aktivitas filosofis. ${ }^{40}$ Hikmah sebagai aktivitas kefilsafatan berakar dari ayat-ayat al-Qur'ān, yaitu surah al-Ḥashr [59]: 2, al-A'rāf [7]: 184, al-An'ām [6]: 75, al-Ghāshiyah [88]: 16-17, dan Âl 'Imrān [3]: 191. Dengan ayat-ayat ini, Ibn Rushd tidak kemudian memahami ayat di atas sebagai hikmah dalam pengertian tekstualnya, sebagaimana dilakukan para pemikir pendahulunya, seperti halnya al-Shāfi $i \bar{r}$. Justru sebaliknya, melalui beberapa ayat tersebut, Ibn Rushd hendak mengajak semua kalangan agar senantiasa mengoptimalkan akal budi, serta perlunya melakukan penalaran terhadap semua entitas alam semesta, sehingga dapat mengantarkan manusia pada titik kebenaran sesungguhnya. Karenaya_-dalam pandangan Ibn Rushd—syariat Islam sama sekali tidak bersebrangan dengan Islam. Sebaliknya syariat dan filsafat adalah

\footnotetext{
38 al-Bannā, Tajdìd al-Islām, 442.

${ }^{39}$ al-Shāfíî̀, al-Risälah,78.

40 Mukhammad Zamzami, "Konsep Revivalisme Humanis Jamal al-Banna" (Disertasi--Institut Agama Islam Negeri Sunan Ampel Surabaya, 2012), 121.
} 
satu kesatuan yang saling mengisi dan menguatkan, yang dalam teks al-Qur'ān terwujud dalam lafal hikmah. ${ }^{41}$ Jika diamati lebih dalam lagi, persepsi Ibn Rushd bahwa hikmah adalah kefilsafatan, lebih banyak dipengaruhi oleh cara berpikir dirinya sebagai seorang filsuf. Dalam perkembangan berikutnya, buah pikir Ibn Rushd tersebut kemudian diadopsi oleh Suhrawardī al-Maqtūl. Meski secara konseptual Suhrawardī menggunakan terminologi berbeda, al-Hikmah al-Ishräqìyah atau filsafat iluminasi, ${ }^{42}$ namun secara substansial kedua pemikir tersebut diikat oleh cara pandang sama, yakni sama-sama menekankan hikmah dalam al-Qur'ān sebagai aktivitas kefilsafatan.

Selain Ibn Rushd, pemikir lain yang mengelompokkan hikmah dalam al-Qur'ān sebagai aktivitas kefilsafatan adalah Armahedi Mahzar. Namun di sini, Armahedi lahir menawarkan konsep yang sedikit berbeda, di mana dirinya membahasakan hikmah dalam alQur'ān sebagai al-Hikmah al-Waḥdatīyah, atau dalam bahasa populernya dikenal dengan filsafat integralisme. Menurut Armahedi, term al-Hikmah al-Wahdatīah pada dapat menjadi jalan tengah atas perdebatan yang selama ini terjadi, khususnya antara al-Hikmah alMashäyah (filsafat paripatetik) dan al-Hikmah al-Ishräqīyah (filsafat iluminasi) yang digagas oleh Suhrawardī. ${ }^{43}$ Untuk menguatkan tesisnya ini, Armahedi menyandarkan argumentasinya pada ayat al-Qur'ān, tepatnya surah al-Nisā' [4]: 113. Ayat tersebut dijadikan sebagai landasan normatif untuk membangun konstruksi filosofisnya tentang hikmah sebagai al-Hikmah al-Wahdatīyah.

c) Hikmah sebagai Penguat Sosial

Salman Ghonim tercatat sebagai pemikir yang ada dalam golongan ini. Dasar pemikiran Ghonim berangkat dari asumsi bahwa hikmah merupakan instrumen penguat sosial. ${ }^{44}$ Tesisnya ini diadopsi langsung dari dari ayat-ayat al-Qur'ān, beberapa di antaranya adalah Q.S. Āl 'Imrān [3]: 79, Q.S. al-Shu'arā [26]: 83, Q.S. Maryam [19]: 12, dan Q.S. al-An‘ām [6]: 57. Berdasarkan keseluruhan ayat ini, hikmah dalam pengertian Ghonim kemudian disimpulkan sebagai sejenis rasa atau kekuatan untuk fokus serta komitmen dalam menyelesaikan

${ }^{41}$ Ibn Rushd, Fașl al-Maqäl wa Taqrìr mä bayn al-Sharīah wa al-Hikmah min al-Ittisäl (Beirut: Dār al-Mashriq, 1986), 27-28.

42 Suhrawardī, Hikmat al-Ishrāq (Teheran: al-Muștafā, 1963), 20.

43 Armahedi Mahzar, Islam Masa Depan (Bandung: Penerbit Pustaka, 1993), 124-131.

44 Muhammad Salman Ghonim, Kritik Ortodoksi: Tafsir Ayat Ibadah, Politik, dan Feminisme, terj. Kamran Asad Irsyadi (Yogyakarta: LKiS. 2000), 60-61. 
persoalan-persoalan sosial yang terjadi di tengah masyarakat. Hikmah dapat memperkuat relasi sosial masyarakat tertentu, menjauhkan mereka dari setiap perpecahan, dan menghindarkan masyarakat dari segala bentuk pertentangan. Dalam pembacaan lebih luas, hikmah dalam pengertian Ghonim memiliki arti menghadirkan stabilitas sosial di kalangan masyarakat akar rumput. Namun demikian, penjelasan Ghonim di atas bukan tanpa kelemahan. Beberapa kalangan menilai argumentasi Ghonim yang terlampau luas ini menimbulkan tafsir dari banyak kalangan. Jika dianalisis lebih kritis, pembacaan Ghonim di atas memiliki konsekuensi tersendiri yang dapat menimbulkan kerancuan tafsir. Bahwa akan timbul anggapan yang menilai hikmah tidak beda jauh dengan peran kekuasaan dalam politik, yaitu samasama berfungsi untuk mengatur atau mengkondisikan masyarakat. ${ }^{45}$

d) Hikmah sebagai Kontrol Kekuasaan

Daniel Madigan barangkali boleh dibilang sebagai pemikir berbeda dengan sebelumnya, dirinya mencoba melakukan pembacaan berbeda terhadap hikmah. Salah satu unsur perbedaannya adalah sikap dirinya yang berusaha menjauh dari perdebatan antara hadis dan kefilsafatan, sebagaimana yang terjadi antara Ibn Rushd dan al-Shāfíī. Jika alShāfíī menekankan makna hikmah pada sunnah, dan Ibn Rushd lebih kepada kefilsafatan, maka Madigan lebih memilih menyandarkan langsung pemikirannya terhadap kata hikmah saja, yakni berdasarkan akar katanya. Menurutnya, berdasarkan akar katanya kata hikmah mengandung indiksikalitas dua makna sekaligus, yakni hukum dan kekuasaan. ${ }^{46}$ Hukum berarti sekumpulan perangkat nilai dan norma yang berfungsi untuk menciptakan dan menjaga keteraturan masyarakat, sedangkan kekuasaan merujuk pada kemampuan diri menularkan pengaruh pada orang lain, meski yang demikian bertentangan dengan keinginan pribadi. Persisnya, dua makna tersebut merupakan perwujudan dari kata hikmah dari ragam bentuk gramatikalnya, yakni ḅukm, ḅäkim, ḥakam atau juga ḅukamä'. Untuk menguatkan proposisinya tersebut, Magdian kemudian merujuk pada teks al-Qur'ān dan menselarasakannya dengan ayat-ayat hikmah, beberapa di antaranya Q.S. Āl 'Imrān [3]: 81, Q.S. al-Aḥāb [33]: 34, Q.S. al-Baqarah [2]: 251, Q.S. Sad [38]: 20, Q.S. al-Zuhkruf [43]: 63, Q.S. al-Qamar [54]: 5, Q.S. al-'Ankabūt [29]: 27 dan al-H.adīd [57]: 26.

\footnotetext{
${ }^{45}$ Ibid., 60-61.

46 Daniel Madigan, The Qur'an's Self-Image: Writing and Authority in Islam's Scripture (New Jersey: Princeton University Press, 2001), 93-96.
} 
Dalam ihwal ini, Daniel sampai pada kesimpulan bahwa makna hikmah bukan saja kebijaksanaan sebagaimana normalnya, tetapi kebijaksanaan yang berkaitan kuat dengan kekuasaan, petunjuk Tuhan, dan pemerintahan. ${ }^{47}$

\section{Hikmah dan Ruang Inklusif dalam Pemikiran Islam}

Diskursus tentang pemikiran Islam sesungguhnya telah berlangsung dalam rentang waktu cukup panjang, bahkan pembahasan tentangnya telah bergulir lama bersamaan dengan kemunculan Islam itu sendiri. Dalam perjalanan yang cukup panjang tersebut, diskursus pemikiran Islam dihadapkan pada banyak dinamika. Pada periode tertentu, pemikiran Islam menemukan momentum di mana akal dengan kemampuan berpikirnya menemukan ruang bebasnya. Pada periode ini, pemikiran Islam ditandai oleh penerimaan terhadap rasionalitas, ilmu pengetahuan, dan budaya. Pada periode tertentu juga, pemikiran Islam mengalami kemandekan, bahkan kemunduran. Nalar kritis Islam menjadi inferior karena harus tunduk pada pemikiran-pemikiran sebelumnya (baca: taqlid $).{ }^{48}$ Hal ini terjadi seiring tumbuhnya sikap 'permusuhan' dirinya terhadap aktivitas nalar (baca: filsafat), serta berkembangnya tradisi berpikir yang mempertentangkan Islam dengan realitas di luar dirinya, seperti halnya ilmu pengetahuan, budaya, rasionalitas, dan terutama segala produk modernisme kontemporer yang lahir dari rahim sekularisme barat. Fase kemunduran pemikiran Islam mengalami titik puncaknya setelah munculnya berbagai aliran Islam ortodoks. Mereka lebih memilih kembali pada teks normatif Islam dan mengamini hasil pemikiran pemikir masa lampau, dan pada saat bersamaan berusaha menjauhkan akal dari fungsi strategisnya sebagai aspek fundamental beragama. Pada tahap ini, kita menyaksikan aktivitas pemikiran Islam menemukan jalan buntu, bahkan beberapa teolog lebih memilih menghukuminya sebagai sikap pertentangan terhadap ajaran agama (baca: haram) yang sesungguhnya.

Pada penggalan periode lainnya, diskursus pemikiran Islam mengalami tantangan terbesarnya ketika Islam dengan segala perkembangan pemikirannya tidak dapat mengakomodir segala bentuk perbedaan, khususnya di lingkup internal Islam sendiri.

\footnotetext{
47 Ibid.

${ }^{48}$ Jalāl al-Dīn al-Suyūṭ̄, al-Radd 'alà Man Akblada ilā al-Ard wa Jabila anna al-Ijtihāed fi Kull 'Așr Fard (Beirut: Dār al-Fikr, 1983), 117-119.
} 
Berkembangnya Islam ke dalam banyak tradisi dan golongan, antara kelompok tradisionalis dan modernis, antara Islam normatif dan Islam dinamis, pada akhirnya menimbukan dinamika sendiri. ${ }^{49}$ Pada titik tertentu, berwujudnya Islam ke banyak golongan memberikan pengaruh positif, demikian karena semakin memperkaya khazanah pemikiran dan keilmuan di tataran internal Islam sendiri, dan menjadi medium semakin meluasnya penyebaran Islam di jagat bumi. Di titik yang berbeda, keanekargaman pemikiran Islam menimbulkan pengaruh negatif, karena tidak jarang menimbulkan pertentangan, seperti halnya benturan pemikiran yang melibatkan kelompok satu dengan kelompok lainnya. Pada tahap ini, tingkat inklusivitas permikiran Islam berada pada titik terendah, karena ketiadaan kemampuan diri mengkondisikan sekian perbedaan pemikiran yang berkembang pesat pada masanya. Berkenaan dengan ini, tesis John L. Esposito tentang problem integrasi Islam di tengah menggeliatnya sentimen atas nama keanekaragaman aliran dan pemikirannya, dalam batasan-batasan tertentu menemukan ruang kebenarannya. ${ }^{50}$

Sekarang, di tengah derasnya arus globalisasi dan proyek modernitas, serta kian kompleksnya problem religio-politik kontemporer, Islam beserta pemikiran di dalamnya dihadapkan pada banyak permasalahan baru. ${ }^{51}$ Problem pemikiran Islam bukan lagi berkaitan dengan kemajemukan di tataran internalnya, namun juga berkaitan dengan isu-isu kekinian yang tumbuh menyubur seiring menggeliatanya perilaku sentimen atas nama identitas. Isu keragaman paham dan aliran kegamaan Islam, seperti halnya pluralitas, sekularisasi, eksklusivisme, inklusivisme, radikalisme, fundamentalisme, dan seabrek gerakan modernitas yang berorientasi pada nalar kekerasan, ${ }^{52}$ kesemuanya merupakan persoalan sosial keagamaan kontemporer yang akan lebih banyak mendominasi ruang diskursus Islam. Harus diakui jika dalam dua dekade terakhir ini, bangunan wacana pemikiran Islam lebih banyak berkutat seputar isu-isu di atas. Dan celakanya, paling dominan wacana tersebut dibangun bukan dalam instrumen dialog produktif yang berorientasi pada terciptanya

\footnotetext{
${ }^{49}$ Fachri Ali dan Bahtiar Effendy, Merambah Jalan Baru Islam Rekonstruksi Pemikiran Islam Indonesia Masa Orde Baru (Bandung: Mizan, 1986), 9.

${ }^{50}$ John L. Esposito, Masa Depan Islam: Antara Tantangan Kemajemukan dan Benturan dengan Barat, terj. Eva Y. Nukman dan Edi Wahyu SM (Bandung: Mizan, 2010), 33.

51 Azyumardi Azra, Konflik Baru Antarperadaban (Jakarta: RajaGrafindo, 2002), 9.

52 Abd A'la, Jahiliyah Kontemporer dan Hegemoni Nalar Kekerasan (Yogyakarta: LKiS, 2014), 20.
} 
satu gagasan revolusioner, namun lebih mengarah pada pertarungan kontraproduktif yang cenderung destruktif. Konsekuensinya, bangunan diskursus pemikiran Islam yang seperti ini bukan lagi menghasilkan simpulan fundamental dalam bentuk sintesis. Sebaliknya, yang muncul adalah pola berpikir otoritarian dan logosentrisme yang memiliki kecenderungan untuk menghakimi, atau lebih tepatnya menyesatkan kelompok dan golongan lain yang tidak sepaham dengannya. Ironisnya, dalam banyak kesempatan pertentangan dalam wilayah ini kerapkali berujung pada aksi konflik fisik yang tidak jarang memakan banyak korban.

Masih menggeliatnya perilaku sentimen atas nama keagamaan yang bercokol pada paham atau aliran keagamaan Islam tertentu, secara langsung telah mengundang perhatian banyak kalangan, baik yang berlatar ilmuan, pemikir, maupun para teolog. Pada tahap ini, semua kalangan sepakat pentingnya memunculkan satu spektrum pemikiran kekinian yang memiliki visi universal. Yakni satu pemikiran keagamaan yang tidak saja menawarkan jalan keluar atas problem sosial keagamaan masyarakat, namun juga dapat menjalin sinergitas dengan konteks sosial yang berlaku pada masanya. Problem menyangkut pergesekan dan benturan antarpemikiran dalam tubuh Islam akan dapat tertangani ketika semua perbedaan tersebut dibangun atas dasar inklusivitas. Menanamkan kesadaran diri untuk selalu melihat perbedaan sebagai satu keniscayaan, dan pada saat bersamaan menanamkan sikap kesediaan diri untuk senantiasa hidup bersama di tengah keberagaman dan kemajemukan.

Tentang inklusivitas dalam pemikiran Islam, wacana ini sejatinya bukan hal baru, melainkan telah bergulir lama bersamaan dengan term-term lain, seperti halnya terminologi Islam pluralis, Islam modernis, Islam tradisionalis, dan lain sebagainya. Pada masanya, istilah inklusivitas mengambil tempat dalam pemikiran Islam bertujuan untuk mengimbangi, atau bahkan menangkal berkembangnya ekstremitas pemikiran Islam, seperti halnya pemikiran yang bercorak literalis dan tekstual normatif. Secara umum, berdasarkan latar genealogisnya, Islam inklusif dimunculkan sebagai antithesis kemunculan Islam eksklusif. Dalam konteks ini, jika Islam eksklusif kental dengan karakternya yang begitu normatif, maka sebaliknya Islam inklusif memilih bersikap dinamis. Karena karakternya yang dinamis tersebut, Islam inklusif senantiasa bersikap terbuka dan melebur diri, bukan saja dengan antarkelompok Islam, 
namun juga dengan agama-agama di luar dirinya. Dalam banyak kesempatan, Islam inklusif seringkali mengundang reaksi keras kalangan Islam tradisional dan ekstrem kanan. Kelompok ini menggolongkan Islam inklusif sebagai sebuah penyelewengan beragama, bahkan pengingkaran terhadap ajaran ketauhidan Islam. ${ }^{53}$ Sampai pada batasan ini, penting kiranya untuk dicari tahu jawabannya, apa yang dimaksud dengan inklusif (pemikiran) Islam?

Secara etimologi, kata inklusif berakar dari bahasa inggris, inclusive yang memiliki arti sampai dengan dan termasuk. ${ }^{54}$ Sebagai buah pemikiran teologis, term inklusif identik dengan nama besar Karl Rahner, seorang teolog Katolik yang pada masanya dikenal sebagai aktifis Hartford Seminary atau Duncan Black Macdonald Center for MuslimChristian Relations. Pada masanya, inklusif merupakan aliran yang menolak ajaran Kristen yang berasumsi bahwa Tuhan mengutuk setiap mereka yang tidak menjadikan Injil sebagai satu-satunya jalan keselamatan. Sebaliknya, menurut Rahner, mereka tetap memperoleh keselamatan ilahi, meskipun bukan melalui kehadiran Yesus. Karl Rahner menggolongkan kelompok ini sebagai anonymous Christian (Kristen tanpa nama). ${ }^{55}$ Pada perkembangan selanjutnya, pemikiran Karl Rahner di atas kemudian diistilahkan berkembang dengan sebutan inklusivisme, dinisbatkan pada pemikiran Karl Rahner tentang adanya kebenaran pada setiap agama-agama dunia. Hal yang perlu dipertegas di sini adalah, inklusivisme tidak dalam arti menyamakan agama-agama, melainkan lebih kepada pengakuan atas kebenaran ajaran dalam agama-agama, sehingga jalan keselamatan tidak berada dalam monopoli satu kelompok atau golongan tertentu saja. Karenanya, secara konseptual, term ini berbeda dengan ajaran relativisme dan kosmopolitanisme.

Menurut Nata, term inklusif ditujukan untuk menunjukkan paham keberagaman yang didasarkan pada pandangan bahwa setiap agamaagama dunia beserta ajaran dan pemikirannya memuat kebenaran masing-masing melalui pesan moral yang terkandung di dalamnya. ${ }^{56}$ Semua agama mutlak mengajarkan kedamaian, cinta kasih, dan

\footnotetext{
53 Abuddin Nata, Peta Keragaman Pemikiran Islam di Indonesia (Jakarta: Rajawali Press, 2001), 163.

${ }^{54}$ John M. Echols dan Hassan Shadily, Kamus Inggris Indonesia (Jakarta: Gramedia, 1996), 316.

55 Ahmad Tajrid, "Kebenaran Hegemonik Agama”, Jurnal Walisongo, Vol. 20, No. 1 (2012), 199.

${ }^{56}$ Nata, Peta Keragaman Pemikiran, 188.
} 
penghormatan terhadap nilai-nilai kemanusiaan. Karenanya, dalam pengertian kontekstualnya, terminologi inklusif memiliki arti tidak semata mengandung arti kenyataan tentang adanya keanekaragaman, melainkan mensyaratkan pada keterlibatan terhadap kemajemukan dalam arti praksisnya. Menjunjung tinggi nilai toleransi dan menanamkan sikap penghormatan yang besar terhadap segala bentuk perbedaan. Baik itu perbedaan dalam dimensi kesektean, ritual keagamaan, atau bahkan menyangkut suatu yang abstrak sekalipun, seperti halnya dimensi pemikiran.

Tidak jauh berbeda dengan definisi di atas, Noercholish Madjid (1939-2005) mengartikan inklusivisme sebagai satu paham agama yang berusaha mengkaji suatu ajaran agama atau aliran keagamaan tertentu, di mana dengan upaya tersebut muncul kesadaran diri untuk tidak melakukan klaim sepihak, sehingga tidak ada monopoli kebenaran berpikir dalam beragama. ${ }^{57}$ Sedangkan menurut Alwi Shihab, inklusivisme adalah satu ciri paham keagamaan tertentu yang menanamkan kesediaan diri untuk mengakui setiap kebaikan yang muncul dari lingkungannya, sekalipun itu muncul dari penganut agama atau paham keagamaan di luar dirinya. ${ }^{58}$ Pengakuan terhadap kebaikan mengandung arti kesepahaman bahwa setiap kebaikan, dari mana pun dan siapa pun itu datangnya, tetap akan mendapatkan pahala dari tuhan. Hampir sama dengan dua pemikir sebelumnya, Azyumardi Azra menambahkan, bahwa sebutan lain teologi inklusif adalah teologi kerukunan. ${ }^{59}$ Kerukunan dalam makna ini adalah menyangkut dengan semua hubungan, baik hubungan dengan sistem keyakinan di luarnya, maupun hubungan antarkelompok di dalam agam itu sendiri. Dengan demikian, jika mengacu pada keseluruhan pengertian di atas, dapat disimpulkan bahwa tema besar Islam inklusif menitikberatkan pada tema-tema pokok, seperti halnya keluwesan diri, toleransi, universalitas, dan segala bentuk penghormatan terhadap keanekaragaman, khususnya dalam dimensi berpikir.

Dalam pandangan penulis, jika dilihat dari segi bentuknya, inklusivisme Islam dapat dibagi menjadi dua bagian, yaitu: Pertama, inklusivisme ke luar. Yaitu sikap penerimaan terhadap segala jenis perbedaan yang ada pada setiap agama di luar dirinya. Konteks

${ }^{57}$ Noercholish Madjid, Teologi Inklusif Cak Nur (Jakarta: Kompas, 2001), 34.

${ }^{58}$ Alwi Shihab, Islam Inklusif: Menuju Sikap Terbuka dalam Beragama (Bandung: Mizan, 1998), 35.

59 Zain Abidin, "Islam Inklusif: Telaah atas Doktrin dan Sejarah", Junrnal Humaniora, Vol. 4, No. 2 (2013), 1278. 
penerimaan di sini bukan dalam arti mengakuinya sebagai sebuah keyakinan diri yang kemudian menggeser keyakinan semula. Makna penerimaan di sini lebih pada pengakuan diri atas keberadaan pesan moral yang ada di setiap masing-masing agama. Hal ini didasarkan pada kenyataan bahwa setiap agama memuat ajaran moralitas bagi setiap pemeluknya, baik itu agama samawi maupun agama nonsamawi. Kedua, inklusivisme ke dalam. Sikap ini mengandaikan adanya sikap kesediaan diri hidup berdampingan dengan kelompok atau aliran keagamaan yang ada di dalam internal Islam sendiri. Sebagaimana diketahui bersama, dalam diri didapati banyak beragama kelompok dan aliran, di mana setiap dari mereka memiliki pendekatan masingmasing dalam memahami dan menafsirkan makna ajaran Islam. Pendekatan berbeda pada gilirannya melahirkan pemahaman dan praktik keislaman berbeda pula. Kenyataan inilah yang kemudian dapat kita lihat dari keberadaan aliran dan kelompok Islam, seperti halnya antara Sunnī dan Shī'ah, ${ }^{60}$ antara kelompok penganut tasawuf dan kaum teosofis. Begitupun dalam hal pemikiran, fakta keragaman Islam tergambar jelas di banyak aspek. Misal, dalam aspek teologi ada kelompok Jabarīyah, Qadarīyah, Mu'tazilah, dan Ash'arīyah. Begitupun dalam wilayah fiqh, kita mendapati empat mazhab besar, yakni mazhab Shāfíīìah, Mālikīyah, Ḥanbalīyah, dan Ḥanafìyah.

Lawan dari inklusif adalah eksklusif, jika inklusif meniscayakan pada pengakuan terhadap perbedaan, maka sebaliknya eksklusif mengandaikan pada penutupan diri terhadap segala pemikiran keagamaan yang berseberangan dengannya. Dalam definisi etimologinya, inklusif memiliki akar kata dari bahsa inggris, exclusive yang berarti sendirian, dengan tidak disertai orang lain, terpisah dari yang lain, berdiri sendiri, semata-mata dan tak ada sangkutpautnya dengan yang lain. ${ }^{61}$ Sedangkan dalam pengertian terminologinya, eksklusif umumnya didefinisikan sebagai sikap diri yang cenderung memandang keyakinan, pandangan, pikiran, dan prinsip diri sebagai suatu yang paling benar. Sederhananya, eksklusivisme mengandaikan pada monopoli kebenaran. Pada banyak tempat, eksklusivisme didominasi oleh tradisi keagamaan yang mengedepankan cara berpikir tekstual dan normatif. Ciri umum kelompok ini adalah ketidaksediaan diri menjalin kerja sama dengan kelompok di luar mereka. Karena

\footnotetext{
${ }^{60}$ Said Aqil Siradj, Menggagas Teologi Perdamaian Sunni-Syiah di Indonesia “, Teosofi, Jurnal Tasawnuf dan Pemikiran Islam, Vol. 3, No. 3 (2012), 325,

${ }^{61}$ Echols dan Shadily, Kamus Inggris Indonesia, 222.
} 
sifatnya ini, mereka lebih suka memisahkan diri dari lingkungannya. Tidak ada aktivitas dialog ataupun proses tukar pikir, karena dalam pandangan mereka konsep kebenaran bersifat tunggal yang hanya berlaku bagi kelompok dan golongannya saja. Bagi mereka, ajaran Islam bersifat final, sebagaimana tertuang jelas dalam sumber alQur'ān, Hadis, dan hasil ijtihad para ulama terdahulu. Karenanya, setiap bentuk pemikiran baru yang berusaha merekonstruksi teks-teks keIslam an, menyegarkan kembali hukum-hukum Islam, sepenuhnya tidak dapat diterima dan dibenarkan adanya.

Dengan demikian, jika merujuk pada keseluruhan penjelasan di atas, diskursus seputar inklusivisme pemikiran Islam mengisyaratkan pada tema-tema berikut: pertama, kebebasan, konsep kebebasan di sini bukan dalam pengertian ekstrem seperti dipahami masyarakat umum, berbuat semaunya dan memaksakan kehendak untuk kepentingan diri sendiri. Makna kebebasan di sini mengandaikan pada upaya dan komitmen diri untuk senantiasa menjunjung tinggi hak asas kemanusiaan. Salah astunya adalah menyangkut keleluasaan memilih atau menjalankan keyakinan tertentu. Secara teologis, hal menyangkut kebebasan memiliki landasan jelas, baik dari aspek historis maupun tekstual. Secara historis, term kebebasan menemukan kebenarannya melalui Piagam Madinah. Sedangkan dari segi teks keagamaan, term kebebasan menemukan dasarnya melalui sumber otoritas Islam, tepatnya Q.S. al-Baqarah [2]: 256. ${ }^{62}$ Jika dikaitkan dengan pembahasan bikmah, maka konsep kebebasan sebagaimana tertuang dalam ayat di atas, selain merupakan salah satu makna inklusivisme, juga memiliki korelasi kuat dengan pengertian hikmah. Bahwa hikmah dalam pengertiannya sebagai sunnah yang mengandung makna universalitas-sebagaimana didefiniskan al-Shāfí ${ }^{\prime} \bar{i}$-mutlak menyimpan pengakuan yang cukup besar terhadap nilai-nilai kemanusiaan, salah satunya adalah kebebasan. ${ }^{63}$

Kedua, toleransi. Dalam Kamus Besar Bahasa Indonesia (KBBI), toleransi memiliki arti bersifat atau bersikap menenggang (menghargai, membiarkan, membolehkan) pendirian (pendapat, pandangan, kepercayaan, kebiasaan, kelakuan, dan sebagainya) yang

62 "Tidak ada paksaan untuk (memasuki) agama (Islam); sesungguhnya telah jelas jalan yang benar daripada jalan yang sesat. Karena itu barangsiapa yang ingkar kepada Ṭāghūt [162] dan beriman kepada Allah, maka sesungguhnya ia Telah berpegang kepada buhul tali yang amat Kuat yang tidak akan putus. Allah Maha mendengar lagi Maha Mengetahui” (Q.S. al-Baqarah [2]: 256).

63 al-Bannā, Tajdìd al-Islām, 442. 
berbeda atau bertentangan dengan pendirian sendiri. ${ }^{64}$ Konsep toleransi adalah kata kunci dasar dalam inklusivisme, karena inklusivisme sendiri meniscayakan pada kesediaan hidup bersama di tengah keberagaman, serta sikap penghormatan terhadap perbedaan. Kaitannya dengan terminologi bikmah, makna toleransi selain mengandung arti inklusivitas Islam juga memiliki arti perwujudan hikmah. Bahwa hikmah dalam kedudukannya sebagai kebijaksanaan, secara langsung juga mengandaikan makna kesediaan diri untuk menjunjung tinggi prinsip kemanusiaan. Salah satunya adalah melalui sikap toleran. Secara teologis, hubungan hikmah dan toleransi dalam diskursus inklusivitas pemikiran Islam mendapati dalilnya melalui Q.S. al-Kāfirūn [109]: $6 .^{65}$ Selain dari al-Qur'ān, landasan teologis toleransi mendapati penegasannya melalui hadis nabi yang menyebutkan bahwa perbedaan itu adalah rahmat.

Ketiga, pluralitas. Secara konseptual, inklusif memiliki pengertian relatif berbeda dengan pluralis. Jika inklusif mengarah pada perwujudan sikap bagaimana menyikapi perbedaan, maka pluralitas adalah kenyataan (objek) dari perbedaan itu sendiri. Meski secara definitif keduanya mempunyai perbedaan, namun terdapat sisi gradual yang mempertemukan keduanya. Sisi gradual tersebut ada pada komitmen keduanya untuk senantiasa menjunjung tinggi semangat kebersaman di tengah keberagaman. Ditinjau dari aspek teologi Islam, pluralitas menemukan ruang legitimasinya melalui ayat Q.S. al-Hujarāt (49): $13 .{ }^{66}$ Sedangkan pada aspek sosiologis, makna pluralitas dalam pemikiran Islam tergambar jelas dari kenyataan masyarakat Muslim yang majemuk dan beranekaragam. Dalam diskursus pemikiran Islam, tema pluralisme menempati bagian sentral, sebagaimana sentralnya tema kebijaksanaan dalam terminologi hikmah. Pada batasan ini, dapat dikatakan konsep pluralitas adalah perwujudan hikmah alQur'ān. Dirinya memainkan peran dan fungsi fundamental dalam upaya mewujudkan satu tradisi pemikiran Islam yang inklusif.

\footnotetext{
${ }^{64}$ KBBI Online (https://kbbi.web.id/), diakses pada 17 Februari 2015.

65 "Untukmu agamamu, dan untukkulah, agamaku" (Q.S. al-Kāfirūn [109]: 6).

66 "Hai manusia, sesungguhnya kami menciptakan kamu dari seorang laki-laki dan seorang perempuan dan menjadikan kamu berbangsa-bangsa dan bersuku-suku supaya kamu saling kenal-mengenal. Sesungguhnya orang yang paling mulia di antara kamu disisi Allah ialah orang yang paling takwa di antara kamu. Sesungguhnya Allah Maha mengetahui lagi Maha Mengenal”. Q.S al-Hujarāt [49]: 13)
} 
Jika terminologi inklusivisme di atas ditarik ke dalam kajian lebih terfokus, yakni kajian tentang hikmah serta kedudukannya dalam upaya mewujudkan pemikiran Islam yang inklusif, maka akan didapati beberapa poin-poin penting berikut: pertama, hikmah mengandung arti kebijaksanaan berpikir yang melandaskan dirinya pada tiga nilai fundamental, yaitu humanisme, kemaslahatan, dan rasionalitas. Secara leksikal, makna humanisme mengandung arti bahwa struktur fundamental Islam, baik dari segi ajaran dan pemikirannya, kesemunya bermuara pada manusia. ${ }^{67}$ Hukum dan pemikiran Islam dibuat bukan untuk dirinya, melainkan untuk manusia. Jika manusia merupakan objek hukum, maka nalar hukum dan pemikiran Islam harus mampu menerjemahkan kepentingan universalitas hidup manusia. Dalam pengertian inilah, sisi korelasi hubungan hikmah dan inklusivitas pemikiran Islam menemukan ruang persamaannya. Kedua, definisi hikmah sebagai kebijaksanaan, selain berpijak pada nilai humanisme, pun juga berpijak pada nilai kemaslahatan. Dalam arti sederhananya, maslahah identik dengan kebaikan dan kebermanfaatan. Jika dikaitkan dengan hukum atau peraturan Islam (baca: syariat), maslaḥah berbicara tentang manfaat dibalik peruusan dan penetapan hukum ketika perintah itu dilaksanakan. Dalam Islam, konsep maslaḅah adalah elemen pembahasan yang tidak saja penting, namun juga fundamental, demikian karena Islam sendiri mengenal maslahah sebagai tolok ukur diterapkannya suatu syariat atau hukum tertentu, yang dalam terminologi hukum Islam dikenal dengan istilah maqāsid al-sharíah. ${ }^{68}$ Secara substansial, maslahah bermuara pada kepentingan umat, yaitu berupa kedamaian, kesejahteraan, dan ketenteraman. Untuk itu, semua ajaran Islam beserta pemikiran di dalamnya harus berorientasi pada kebaikan (kemaslahatan) umat. Berdasarkan pembacaan inilah, pengertian dan kedudukan hikmah dalam fungsinya sebagai pintu masuk pemikiran Islam inklusif, secara jelas mendapati kebenarannya. Melalui keseluruhan pembacaan di atas, maka jelas sudah bagaimana hubungan hikmah dalam al-Qur'ān pada banyak ayat di dalamnya, memiliki peran dan fungsi fundamental dalam mewujudkan nilai-nilai inklusivitas pemikiran Islam.

Ketiga, selain humanisme dan kemaslahatan, makna hikmah yang terakhir adalah rasionalisme. Secara definitif, rasionalisme memercayai

${ }^{67}$ KBBI Online( https:/ / kbbi.web.id/), diakses pada 17 Februari 2015.

${ }_{68}$ Maulidi, "Maqasid Syariah sebagai Filsafat Hukum Islam: Sebuah Pendekatan Sistem Menurut Jasser Auda", al-Mazāhib, Vol. 3, No. 1 (2015), 1-15. 
bahwa akal dengan sekala kemampuan berpikir dan bernalarnya dapat menjadi satu-satunya instrumen memecahkan setiap permasalahan, meskipun permasalahan tersebut berada di luar jangkauan indra. ${ }^{69}$ Rasionalisme menitiktekankan pada pertimbangan akal sehat daripada emosi dan perasaan. Fungsi rasionalitas hikmah adalah jalan keimanan dalam beragama, dan tidak ada jalan lain menuju kebenaran agama kecuali melalui penggunaan akal. Manusia sebagai hewan berakal memiliki kedudukan sentral dalam nalar al-Qur'ān. Karenanya, setiap rasionalitas yang dijalankan untuk mencari tahu kebenaran beragama, maka semuanya harus berpijak pada kepentingan manusia. Begitupun dengan Islam, setiap aktivitas nalar yang dijlankan untuk merumuskan ajaran, hukum, dan pemikiran di dalamnya, kesemuanya harus memuat keberpihakan kepentingan manusia secara utuh, mendorong keberlanjutan kehidupan manusia, dan menghadirkan kedamaian dan ketenteraman bagi semua umat. Dari sudut pandang ini, makna rasonalitas yang menitikberatkan pada eksistensi manusia, mengandung korelasi kuat dengan cita-cita pemikiran Islam inklusif.

\section{Catatan Akhir}

Hikmah merupakan kebijaksanaan berpikir, bersikap, dan bertindak yang berpijak pada dua hal, yaitu kepandaian berpikir dan kecakapan bertindak. Kepandaian meniscayakan kehadiran akal budi berupa pengetahuan. Konsep pengetahuan dalam hikmah mengandaikan pada diri yang terpelajar, berilmu, dan tercerahkan, sehingga dengannya seorang dapat menjadi pribadi bermanfaat bagi lingkungannya. Sedangkan kecakapan bertindak merupakan representasi diri yang memiliki sensitivitas sosial kuat. Melalui sensivitas diri, seorang akan bergerak aktif untuk terlibat langsug dalam aktivitas sosial masyarakat. Menghindarkan masyarakat dari segala bentuk kesulitan, dan menghadirkan solusi terhadap problematika sosial.

Hikmah dalam al-Qur'ān memiliki landasan cukup kuat. Landasan tersebut dapat dikelompokkan pada tiga wujud nilai hikmah, yakni; humanisme, kemaslahatan, dan rasionalitas. Humanisme dalam hikmah berarti menjadikan manusia sebagai pusat atau sentral. Hikmah dalam Islam mengisyaratkan bahwa setiap ajaran Islam beserta pemikirannya harus dapat menjalin keselarasan dengan nilai kemanusiaan. Adapun kemaslahatan dalam bikmah mengandung arti

${ }^{69}$ KBBI Online (https://kbbi.web.id/), diakses pada 17 Februari 2015. 
kebaikan dan kebermanfaatan. Hikmah dalam pemikiran Islam artinya setiap ajaran dan pemikiran Islam harus memuat kepentingan universalitas, yakni terciptanyan satu realitas keislaman yang menjunjung tinggi prinsip rahmah li al-álamin. Islam penuh maslaḥab yang artinya penuh kedamaian, ketenteraman, dan kerukunan. Sedangkan makna rasionalitas dalam hikmah artinya Islam adalah agama yang menjalin kesesuaian dengan spirit rasional. Karenanya, setiap ajaran dan pemikiran Islam harus dilandaskan pada pertimbangan logis, akal sehat, dan ilmu pengetahuan.

Hikmah dalam pengertiannya sebagai kebijasanaan berpikir yang berpangkal pada akal budi berupa kepandaian dan kecakapan, dalam banyak sisi mempunyai keselarasan dengan inklusivitas pemikiran Islam. Sekurang-kurangnya, hubungan hikmah dalam pemikiran Islam yang inklusif dapat dilihat dari tiga aspek ini. Pertama, inklusif memiliki pengertian toleransi, yakni penerimaan terhadap keberagaman, serta kesediaan diri terlibat aktif di dalamnya. Pemikiran Islam inklusif artinya mengisyaratkan pada satu bangunan pemikiran Islam yang memuat nilai toleransi. Makna toleransi di sini secara eksplisit memiliki keselarasan dengan makna hikmah, yang sama-sama menitikberatkan pada kemaslahatan masyarakat; Kedua, inklusif memiliki makna kebebasan, makna kebebasan di sini meniscayakan pada keleluasaan dirinya untuk menggunakan akal sebagai intrumen untuk mencari kebenaran beragama. Makna ini memiliki kesamaan dengan konsep hikmah, yang melihat aktivitas berpikir dan bernalar sebagai jalan menuju keimanan; dan Ketiga, inklusif memuat makna kebebasan. Arti kebebasan meniscayakan pada perwujudan pemikiran Islam yang universal, dan tidak memaksa. Makna kebebasan dalam terminologi inklusif memiliki titik persamaan dengan hikmah, yaitu sama-sama menekankan pada perwujudan pemikiran Islam universal. Islam yang memberi keleluasaan bagi umatnya untuk memilih jalan kehidupan, termasuk dalam hal meyakini dan menjalan (paham) keagamaan tertentu.

\section{Daftar Rujukan}

A'la, Abd. Jabiliyah Kontemporer dan Hegemoni Nalar Kekerasan. Yogyakarta: LKiS, 2014.

Abdullah, "Hikmah al-Israqiyah: Menelaah Sisi Eksistensialisme Teosofi Transenden Mulla Sadra, Jurnal Sulesana, Vol. 7, No. 2, 2012. 
Abidin, Zain. "Islam Inklusif: Telaah atas Doktrin dan Sejarah", Junrnal Humaniora, Vol. 4, No. 2, 2013.

Ali, Fachri dan Effendy, Bahtiar. Merambah Jalan Baru Islam Rekonstruksi Pemikiran Islam Indonesia Masa Orde Baru. Bandung: Mizan, 1986.

Alūsī (al), Shihāb al-Dīn. Rūḥ al-Ma'ānì fì Tafsìr al-Qư'ān al-Ađ̛̣im wa alSab' al-Mathanī. Beirut: Dār al-Kutub al-'Ilmìyah, 2001.

Azra, Azyumardi. Konflik Baru Antarperadaban. Jakarta: RajaGrafindo, 2002.

Bannā (al), Jamāl. al-Islām Kamā Tuqaddimuh Da'wat al-Ihyā' al-Islāmì. Kairo: Dār al-Fikr al-Islāmīi, 2004.

----. Isträtīizyat al-Da'wah al-Islāmìyah fì Qarn 21. Kairo: Dār al-Fikr alIslāmīi, 2000.

-----. Tajdìd al-Islàm wa I'ädat Ta'sìs Manzüumat al-Ma'rifah al-Islämìyah. Kairo: Dār al-Fikr al-Islāmīi, 2005.

Bāqī (al), Muḥammad Fuād 'Abd. Mu'jam Mufahras li Alfāă al-Qur'ān alKarim. Beirut: Dār al-Fikr, 1992.

Echols, John M. dan Shadily, Hassan. Kamus Inggris Indonesia. Jakarta: Gramedia, 1996.

Esposito, John L. Masa Depan Islam: Antara Tantangan Kemajemukan dan Benturan dengan Barat, terj. Eva Y. Nukman dan Edi Wahyu SM. Bandung: Mizan, 2010.

Fakhry, Madjid. A History of Islamic Philosophy. New York: Colombia University Press, 1983.

Faridah, Ika Fatmawati. "Toleransi Antarumat Beragama Masyarakat Perumahan”, Jurnal Komunitas, Vol. 5, No. 1, 2013.

Ghonim, Muhammad Salman. Kritik Ortodoksi: Tafsir Ayat Ibadah, Politik, dan Feminisme, terj. Kamran Asad Irsyadi. Yogyakarta: LKiS. 2000.

Hanbalī (al), Zayn al-Dīn Abī al-Faraj b. Rajāb. Fatḥ al-Bārū bi Sharḥ alBukbārì, Vol. 1. Madinah: Maktabat al-Ghurabā’, 1999.

Harahap, Khoirul Amnu. 355 Kunci Menjadi Kekasib Allah Sepanjang Masa. Tanggerang: PT. Tangga Pustaka, 2009.

Jamarudin, Ade. "Eksistensi Fungsi Akal Manusia Perspektif alQur'ān”, Jurnal An-Nur, Vol. 4, No. 1, 2015.

Lakonawa, Petrus. "Agama dan Pembentukan Cara Pandang Serta Perilaku Hidup Masyarakat", Jurnal Humaniora, Vol. 4, No. 2, 2013. 
Madigan, Daniel. The Qur'an's Self-Image: Writing and Authority in Islam's Scripture. New Jersey: Princeton University Press, 2001.

Madjid, Noercholish. Teologi Inklusif Cak Nur. Jakarta: Kompas, 2001.

Mahzar, Armahedi. Islam Masa Depan. Bandung: Penerbit Pustaka, 1993.

Maulidi. "Maqasid Syariah sebagai Filsafat Hukum Islam: Sebuah Pendekatan Sistem Menurut Jasser Auda", al-Mazābib, Vol. 3, No. 1, 2015.

Muhtador, Moh. "Pemaknaan Ayat al-Qur'an dalam Mujahadah: Studi Living Qur'an di PP Al-Munawwir Krapyak Komplek alKandiyas", Jurnal Penelitian, Vol. 8, No. 1, 2014.

Muin, Thaib Thahir Abdul. Ilmu Kalam II. Jakarta: Widjaja, 1973.

Munir, Ghozali. "Al-Qur'an dan Sejarah Realitas Umat Manusia", Jurnal At-Taqaddum, Vol. 4, No. 1, 2012.

Musadad, Asep N. "Tafsir al-Qur'an dalam Tradisi Filsafat Hikmah: Analisis Materi Filosofis Tafsir Ayat al-Kursy, Karya Mulla Sadra". Tesis--Universitas Islam Negeri Sunan Kalijaga Yogyakarta, 2016.

Nasr, Seyyed Hossein dan Leaman, Oliver. Ensiklopedi Tematis Filsafat Islam: Buku Pertama, terj. Tim Penerjemah. Bandung: Mizan, 1996.

Nasr, Seyyed Hossein. Ensiklopedi Tematis Filsafat Islam, terj. Tim Penerjemah Mizan. Bandung: Mizan, 2003.

-----. History of Islamic Philosophy from Its Origin to The Present: Philosophy in Land of Prophecy. New York: State University of New York, 2006.

Nata, Abuddin. Peta Keragaman Pemikiran Islam di Indonesia. Jakarta: Rajawali Press, 2001.

Rushd, Ibn. Faș al-Maqäl wa Taqrì mä bayn al-Sharìah wa al-Hikmah min al-Ittisāl. Beirut: Dār al-Mashriq, 1986.

Safri, Arif Nuh. "Otentisitas Risalah Kenabian; Pluralisme dan Kemanusiaan”, Jurnal Esensia, Vol. 13, No. 1, 2012.

Shāfíì (al), Abū 'Abd Allah Muḥammad b. Idrīs. al-Risālah. Beirut: Dār al-Kutub al-'Ilmìyah, 1939.

Shihab, Alwi. Islam Inklusif: Menuju Sikap Terbuka dalam Beragama. Bandung: Mizan, 1998.

Shihab, M. Quraish. Secercah Cahaya Ilahi Hidup Bersama Al-Qur'ān. Bandung: Mizan, 2007.

Siradj, Said Aqil. Menggagas Teologi Perdamaian Sunni-Syiah di Indonesia ", Teosofi, Jurnal Tasawnuf dan Pemikiran Islam, Vol. 3, No. 3, 2012.

Suhrawardī. Hikemat al-Ishrāq. Teheran: al-Muștafā, 1963. 
Sumadi, Eko. "Teori Pengetahuan Ishraqiyyah (Iluminasi) Syihabudin Suhrawardi", Fikrah: Jurnal Ilmu Aqidah dan Studi Keagamaan, Vol. 3, No. 2, 2015.

Suyūṭī (al), Jalāl al-Dīn. al-Radd 'alā Man Akblada ilā al-Arḍ wa Jabila anna al-Ijtihād fi Kull 'Aṣr Farḍ. Beirut: Dār al-Fikr, 1983.

Tajrid, Ahmad. "Kebenaran Hegemonik Agama", Jurnal Walisongo, Vol. 20, No. 1, 2012.

Zahw, Muḥammad Abū. al-Hadìth wa al-Muhaddithūn. Beirut: Dār alFikr, t.th.

Zakariyā, Abū al-Husayn Aḥmad b. Fāris b. Mu'jam Maqāyìs al-Lughah. Beirut: Dār al-Fikr li al-Tarbīyah wa al-Nashr wa al-Tawzī‘ 1998.

Zamzami, Mukhammad. "Konsep Revivalisme Humanis Jamal alBanna". Disertasi--Institut Agama Islam Negeri Sunan Ampel Surabaya, 2012.

----. "Teologi Humanis Jamâl al-Bannâ: Sebuah Rekonstruksi Epistemologis Studi Keislaman", Teosofi: Jurnal Tasawnf dan Pemikiran Islam, Vol. 2, No. 1, 2012. 